\title{
Education Of The Deprived Social Group: With Special Refference to the Girl's Education of Tinsukia District through KGBV (Kasturba Gandhi Balika Vidyalaya) With Field Study.
}

\author{
Rekhamoni Baruah, \\ Deptt. Of Education,Women's College, Tinsukia.Assam(India)
}

\begin{abstract}
Nearly half of the total population in our country(India) are women while majority of them belong to rural area. These women are in a very deplorable condition which makes the whole society backward. They are always discriminated from womb to tomb. They are powerless not only politically but also socially and economically due to many causes such as illiteracy, poverty, ignorance, superstitions etc...etc.... Women are considered as the weakest part of our society and they are always deprived social groups from all side.

It is needless to acknowledge that women's literacy \& education levels help secure social equality and human development, higher economic productivity and a tolerant democratic society which the National Policy on Education, 1986 has identified as a challenge in India.

Latest contribution in the field of girls education is made by the SSA mission which introduced a very novel ideal of providing residential schooling facilities to the girls education up to class V111 by a special school called Kasturba Gandhi Balika Vidyalaya (KGBV).

$K G B V$ is a scheme to provide elementary level quality and life skill educational facilities to girl children of the age group of 10-14 years for illiterate girl children, working girl children who have not completed class $1 V-V 11$ and who belong to SC/ST/OBC and minority communities. Under this scheme residential school and hostel accommodation for girls is established in the educationally backward block, towns and minority concentrated areas of all over the country.

In Assam 26(model-1=3 \& model-11=23) nos. of KGBVs running with 1450 children in 13 districts ( as per census 2008-09). There are 3 KGBVs in 3 blocks of Tinsukia district which have been chosen in the most educationally backward areas of the district. All the $3 \mathrm{KGBVs}$ of Tinsukia district included in the present study. The overall influence of these organisations on the girls education at the elementary stage of the district will be analysed and examined by the present study.
\end{abstract}

\section{Introduction :}

India is one of the largest democratic country in the world. It has a quality and systematic education system which has a huge demand. But after the $65 y$ rs. of independence of India we are away from the goal of universal literacy. Till now, SC/ST, Women, rural people etc. are considered as deprived social group of our society in every side. They are suffering a lot of problems and cannot go ahead. Of course, Govt. of India announces many welfare schemes for the weaker section of our society from time to time. These schemes could be either Central, State specific or a joint collaboration between the centre and the states.

As a deprived social group, the condition of the girl child is always worse than the boys and it is a very big sociological problem of our society. According to the census of 2001, the literacy rate of Assam is $63.3 \%$ ( $71.3 \%$ are male and $54.6 \%$ are female). In 2011, total literacy rate of Assam is $73.18 \%$ (78.8\% are male and $67.27 \%$ are female). This shows that the female literacy rate is quite unsatisfactory in Assam .

To solve this problems, women empowerment is being exercised through constitutional directives and recommendations provided by different committees and commissions from time to time. The New Education Policy of Education 1986, also tried a lot for the provision of equal opportunity of education to the girls and different Government Schemes have been launched for this purpose.

The Government of India has launched a new scheme called Kasturba Gandhi Balika Vidyalaya(KGBV)in August 2004 to provide educational facilities for the girl children between the age group 10-14 years belonging to SC/ST/OBC and Minority communities and families below the poverty line in educationally backward blocks. The objective of KGBV is to ensure access and quality education to the girls of disadvantaged groups of society by setting up residential schools with boarding facilities at elementary level

This Paper attempts to highlight the contribution of KGBV in the field of women education with special reference to Tinsukia District of Assam which are playing significant role in strengthening socioeconomic status of the rural women and thus building confidence and strong personalities within themselves.

In Assam 26 nos. (model-1=3, model-1l=23) of KGBVs are functioning with 1450 children in 13 districts (as per census 2008-2009). All the schools are running in rented and govt. abandoned buildings. . There are two models of KGBV, Model-1 consisting 100 nos. of students \& Model-1l having 50 nos. of students. 
The following table shows the district wise nos. of KGBVs \& their enrolment of our state.......

TABLE NO : 1

District wise no of KGBVs and Enrolment

\begin{tabular}{|l|c|c|c|}
\hline District & No.of $K G B V$ & Model & Children covered \\
\hline Dibrugarh & 1 & $I I$ & 50 \\
\hline Darrang & 3 & $I I$ & 150 \\
\hline Dhemaji & 2 & $I I$ & 100 \\
\hline Sivasagar & 1 & $I I$ & 100 \\
\hline Nalbari & 2 & $I I$ & 250 \\
\hline Karbi Anglang & 5 & $I I$ & 50 \\
\hline NC Hills & 1 & $I I$ & 150 \\
\hline Tinsukia & 3 & $I I$ & 150 \\
\hline Dhubri & 3 & $I I$ & 200 \\
\hline Kamrup & 2 & $I$ & 100 \\
\hline Barpeta & 1 & $I$ & 50 \\
\hline Sonitpur & 1 & $I I$ & 50 \\
\hline Lakhimpur & 1 & $I I$ & 1450 \\
\hline Total & 26 & 26 & \\
\hline
\end{tabular}

(Census 2008-2009)

In Tinsukia district there are $3 \mathrm{KGBVs}$ in 3 blocks of Tinsukia district which have been chosen in the most educationally backward areas of the district. These are Hapjan CD block, Itakhooli CD block, Guijan CD block. All the $3 \mathrm{KGBVs}$ of Tinsukia district included in the present study. The overall influence of these schools on the girls' education at the elementary stage of the district will be analysed and examined by the present study.

In the census report of 2011, the complete literacy condition of the entire population is reflected in the following manner---

TABLE NO 2

Population statistics as per 2011 census of Tinsukia District.

\begin{tabular}{|c|c|c|}
\hline 1) & Total Population -------- & 1316948. \\
\hline 2) & $--\cdot--\cdot--$ & 675986. \\
\hline 3) & 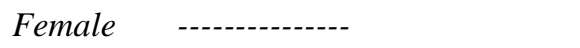 & 640962. \\
\hline 4) & No.of children in 6-14 yrs. Age---- & 208882. \\
\hline 5) & No.of school going children 6-14 yrs. Ag & $e---143788$ \\
\hline 6) & $\begin{array}{l}\text { No.of out of school \& drop-out children } \\
\text { 6-14 yrs. Age. }\end{array}$ & 65094. \\
\hline 7) & Literates & ---- 809796. \\
\hline 8) & Male literates & ----- 457356. \\
\hline & Female literates & ---- 352440. \\
\hline & Literacy rate & $----70.92 \%$ \\
\hline 11) & Density of population & -----347 per sq. km. \\
\hline 12) & Growth rate & $---14.51 \%$ \\
\hline 13) & Sex ratio (no. of female per 1000 men) & -948. \\
\hline
\end{tabular}

In the census of 2011,Total population of Tinsukia district is 1,31,6948,out of which 6,75,986 are male and $6,40,962$ are female. Literacy rate is $70.92 \%$ (male- $72.92 \%$ and female- 63.54\%). Population in Tinsukia district is very dense and various types of people live here. Majority of the people here are business man and come here with commercial purpose. But their status is not same. People belong to various economic, social and cultural complexes. We also find large group of people belonging to tribal community(ST/SC), MOBC and OBC communities. Some of them do not have steady income and hence they live below the poverty line mainly in the rural areas. These people cannot send their children to the educational institutions regularly and hence they become irregular in classes and some of them become dropout cases.

Kasturba Gandhi Balika Vidyalaya is an important scheme of Central Government through which they are trying to eradicate illiteracy from the society at large.

\section{Rationale :}

The scheme of KGBV was launched by the government of India in August 2004 for setting up 750 residential schools with free hostel facilities at upper primary level for girls in the identified educationally backward blocks according to 2001 census, having rural female literacy rates below the national average and the gender gap in literacy more than the national average. The KGBV Scheme is merged with SSA in the XIth plan with effect from Ist April'2007. The scheme intends the ensure access and quality education to girls belonging largely to the disadvantaged group of society i,c, ST/SC/OBC \& Minorities. 
The scheme has given much stress on women education so that a change can be brought in the status of women. It is a very new scheme introduced by central Government for encouraging the rural women but till date it is not much familiar among them. So, it is our duty to bring awareness about the KGBV Scheme among these people.

In this paper a sincere attempt has been made to highlight the present scenario of the all KGBVs of Tinsukia District with a field study.

\section{Objective :}

The objective of this paper is to highlight the contribution of KGBVs in the field of girl's education as well as empowering women at the elementary stage in the backward areas \& for the backward communities of Tinsukia District.

\section{Methodology :}

The study is conducted by descriptive survey method. Interview schedules are used in collecting information from the respondent. The researcher has visited all the three schools and collected data with help of face to face interview with students, teachers and parents, questionnaires to teachers and students and observation of the environment of the schools.

\section{Population And Sample :}

The study covers 3 KGBVs of Tinsukia district. 5 students from every class of every school(randomly selected). 5 teachers from every KGBVs(randomly selected). 5 guardians from three KGBVs (randomly selected). (Students=45, Teachers=15, Guardians=5).

\section{V1. Findings :}

The study is confined to only three KGBVs of Tinsukia District established under Itakhuli Block,Guijan Block \& Hapjan Block. All the three schools of Tinsukia district are found to be of model-1l (50 students in each school).

I found from my visit that KGBVs are running smoothly \& these are successful educational institutions in the case of rural and backward woman education. The education provided by these schools are of high qualitative value $\&$ it has vocational bias.

The detailed findings of the students in the three KGBVs are represented in the following tables according to their age, class and caste.

Table No.3

Details of the student

CASTE

\begin{tabular}{|l|l|l|l|}
\hline CASTE & HAPJAN & ITAKHULI & GUIJAN \\
\hline$S C$ & NIL & NIL & NIL \\
\hline$S T$ & 8 & 5 & 26 \\
\hline OBC/MOBC & 39 & 34 & 20 \\
\hline TEA TRIBE & 3 & 11 & 4 \\
\hline \multicolumn{1}{|c|}{ TOTAL } & 50 & 50 & 50 \\
\hline
\end{tabular}

\section{CLASS}

\begin{tabular}{|l|l|l|c|}
\hline CLASS & HAPJAN & ITAKHULI & GUIJAN \\
\hline V & NIL & NIL & 10 \\
\hline VI & 19 & 23 & 10 \\
\hline VII & 7 & 10 & 11 \\
\hline VIII & 24 & 17 & 19 \\
\hline TOTAL & 50 & 50 & 50 \\
\hline
\end{tabular}


Education Of The Deprived Social Group : With Special Refference To The Girl's Education Of

\begin{tabular}{|l|l|l|c|}
\hline \multicolumn{1}{|c|}{ AGE } & HAPJAN & ITAKHULI & GUIJAN \\
\hline $10-11$ Yrs. & \multicolumn{1}{|c|}{ NIL } & 5 & 9 \\
\hline $11-12$ Yrs. & 17 & 12 & 8 \\
\hline $12-13$ Yrs. & 9 & 22 & 13 \\
\hline $13-14$ Yrs. & 24 & 11 & 14 \\
\hline $14-15$ Yrs. & NIL & NIL & 6 \\
\hline TOTAL & 50 & 50 & 50 \\
\hline
\end{tabular}

Students of these schools belong to ST,SC,OBC/MOBC and tea tribal community. There are generally three classes VI,VII,VIII but in some cases class $\mathrm{v}$ is also retained for the educationally backward girls.

From my experiences by visiting these schools I can describe the following facts as my general observation-----

TABLE NO : 4

List of items provided by SSA to KGBVs (as found by the Researcher)

\begin{tabular}{|l|l|}
\hline Material Resources & Human Resources \\
\hline 1. Two tired beds & 1.Warden cum teacher. (no.1), Residential \\
\hline 2.Steel almirah, chair, table,desk,bench. & 2. Full-time teacher ( no. 3), Residential \\
\hline 3.Necessary utensils, water filter, ges stove. & 3.Part-time teacher (no. 4 ) non-residential \\
\hline 4.Necessary stationery. & 4. Support Staff. \\
\hline 5.Uniforms \& chappals/shoes with sock. & a.Peon, non-residential. ( no. 1) \\
\hline 6.Blackboard,ringbells,TLMs. & b. Chowkider, residential. (no. 1$)$ \\
\hline 7.Play materials, T.V, First-aid box. & c. Cook, residential. ( no.2) \\
\hline 8.Musical instrument. & d. Visiting staff-I. Computer expert \\
\hline 9. Sweater, inner garment. & II. Vocational trainer in dance, \\
\hline 10. Green board & III. Martial art etc. \\
\hline 11. Computer & \\
\hline
\end{tabular}

In the KGBV at Itakhuli Block and Guijan Block I found that the own building of the school. The kitchen and toilet are found to be quite satisfactory. The classrooms, common rooms for teachers are found to be as per the requirement of the students and teacher.

\section{TABLE NO 5}

\section{Environment of KGBVs of Tinsukia District.}

\begin{tabular}{|l|l|l|l|}
\hline Environment & Guijan Block KGBV & Hapjan Block KGBV & Itakhuli Block KGBV \\
\hline General environment & Very good & Not so good & Very good \\
\hline Sanitary environment & good & good & Good \\
\hline
\end{tabular}

\section{Computer literary}

It was observed that computer literacy is a compulsory subject for each and every student and accordingly all of them displayed expertise in handling the instrument. The numbers of computer sets were found to the quite satisfactory.

\section{Co-curricular activities}

All the girls are trained in dance, music, martial arts with expert part time intructors. Sometimes they participate in the state level competition in co-curricular activities of different types and show good performance in competitions.

\section{Vocational training}

One of the strongest point of the KGBVs are their vocational proficiency in different types of activities viz. Stitching and tailoring, Knitting, Weaving, Embroidery, Doll and flower making, Pot painting etc.

TABLE NO : 6 


\begin{tabular}{|c|c|c|c|}
\hline Name of the skill & Itakhuli & Hapjan & Guijan \\
\hline Stitching \& tailoring & Yes & Yes & Yes \\
\hline Knitting & Yes & Yes & Special important \\
\hline Weaving & Special important & Yes & Special important \\
\hline Embroidery & Yes & Yes & Yes \\
\hline Doll making & Yes & Yes & Yes \\
\hline Flower making & Yes & Yes & Yes \\
\hline Pot painting & Yes & Yes & Yes \\
\hline Jute product & Special important & Special important & Yes \\
\hline
\end{tabular}

Excellent training is imparted with specially trained teachers. I came to know from the students that the handicrafts produced by them have good demand in the market. They also earn some pocket money by marketing those items.

In Guijan Block I found 3 sewing machines, two tantshals, and varieties of handicraft like embroidery in bedcover, table cloth, mekhela chaders, gamusha, painted pots, artificial flower etc. In Hapjan Block they were paying special attention at jute product, besides the above mentioned craft and hand work. Similarly in Itakhuli Block girls were learning all the trades with special emphasis on weaving and spinning.

\section{Yoga}

Training in yoga is also an important feature in KGBVs. Through Yoga training, children learn meditation, asana, pranayama etc. which build up their sense of value, discipline and morality.

\section{Stipends}

Students are given a sum of Rupees 600/- per annum which are meant for pocket money of the girls. Girls feel very happy as they get a chance to practice their independence and eventually self confidence could be developed.

\section{Summer Camp and Motivation}

During the time of long vacations camps are organised on Dance, drama, music, sports, martial art etc., which can be appreciated for their motivating force. Through these activities children find opportunities to boost their qualities and uplift their mind from all kinds of narrowness.

\section{Martial Art or Self Defense}

Girls of KGBVs are imparted self defence training which help them in building discipline, courage, confidence and empowerment. The result of the training is fruitful for the girls in building self empowerment, self awereness and sportsman spirit. Selected trainers are engaged in these schools from recognized institutes.

\section{Library facilities}

Sufficient reading books are supplied for promoting reading habits of students of KGBVs. Necessary book selves are also provided to these schools.

\section{Evaluation}

The system of examination and evaluation in these school are supposed to be quite satisfactory. Both short term and long term evaluation are used to maintain continuity of the system.

\section{Parent comments}

I meet five guardians and they are highly appreciated the schools. Some parents have even got the opportunity of educating two to three girls in the same school.

\section{Conclusion}

All the above mentioned observations are made on the basis of interview with the students and teachers of the three KGBVs and actual visit to the schools.

The experience I gathered from the visits to all the schools made me feel that both the academic and nonacademic activities followed in the schools are sufficient for making them prepared for future womanhood. The trainings are sufficient for making them physically, socially, emotionally and psychologically fit persons. They also get training to develop moral and spiritual values. They become well-disciplined, self-confident, enlightened and happy persons. All these qualities will definitely make them complete woman during future days. 
Through the process of interview and questionnaire with the wardens of the KGBV, it is proved that the schools are successful in surveying all the girls of a specific backward block having the inhabitation of SC, ST, OBC. MOBC and minorities. But due to the limitation of seats in the schools many eager and willing girls were deprived from admission.

But those girls who are working as child labors, they are unwilling to come to the school. Problem of mainstreaming is faced by the KGBV of Itakhuli, Bordubi block. But in the other two KGBV of Guijan and Hapjan block there is no problem in mainstreaming as such. As the students of KGBV are very advanced in all the curricular and extra curricular activities, they are liked and wanted by all the local schools.

During mainstreaming, students have to pay for admission, uniform, books and many such purpose. SSA supplies them financial support, but it is given only once. But the problem is that rest of the days, the expenditure has to be borne by the parents only which is difficult for them. It is the secondary reason for dropout after mainstreaming. Many girls becomes married and have to leave school without completing education.

\section{LOOPHOLES OBSERVED BY RESEARCHER}

But still there are Hostel accommodation is not comfortable for both teachers \& students. The rooms are very small in comparison to the number of teachers \& students. 3 nos. full time teachers stay in one single room in two tier bed which is obviously very congested.

G Girls are also given two tired beds \& they feel very uncomfortable during in summer because the air circulation produced by the ceiling fan cannot reach the girls in lower part of the beds.

$\square$ Teachers are being paid in fixed salary which is inadequate.

\section{Suggestions}

- KGBV should be extended to XII standard which is already revealed in the $11^{\text {th }}$ five year plan.

- Teachers should be provided with better salary and attractive service conditions.

- Married teachers of KGBV should be given separate quarters so that they can live with their families and they can render their best services to the students.

- These schools should find more focus and advertisement in the Medias.

- No. of seat's capacities should be increased.

- Provisions to be for made more school's welfare funds.

On the whole observations revealed a very encouraging picture of women's empowerment in these schools. If such opportunities could be provided to all the rural girls in our country, then the entire picture of girls education could be changed. Another important observation which is worth mentioning here is that students are taking an active role in removing the illiteracy of their parents, maintaining cleanliness in their respective homes, giving education in hygiene and sanitation in their neighborhood etc. In this way the girls if properly educated can take a leadership role in the society.

In conclusion, it should be mentioned that more and more this type of residential schools should be established in the educationally backward areas so that the condition of women's education can be improved and empowerment of rural women will be strengthened. The scheme KGBV will be fully successful only when the administration, SSA, teachers, guardians and general public will work whole-heartedly and in a co-operative manner.

\section{Keywords \\ KGBV-Kasturba Gandhi Balika Vidyalaya, SSA-Sarva Siksha Abhijan, SC-Schedule caste, ST- Schedule Tribe, OBC-Other Backward Classes.}

\section{References}

[1]. Some News letters, Journals \& News bulletins from SSA Mission, Assam. 